CFR working paper No. 13-07

Market Transparency and the marking precision of Bond mutual fund managers

G. cici • s. gibson • y. Gunduz • J.J.merrick, jr. 


\title{
Market Transparency and the Marking Precision of Bond Mutual Fund Managers
}

Gjergji Cici, Scott Gibson, Yalin Gündüz, and John J. Merrick, Jr.

June 4, 2014

(First Draft: September 3, 2013)

\begin{abstract}
The validity of the price marks placed on bonds for valuation purposes is important for a diverse group of stakeholders, including investors, mutual fund managers, dealers, pricing services, and financial regulators. We analyze the dispersion of monthend price marks simultaneously placed on identical corporate bonds by different US mutual fund managers before and after TRACE dissemination and introductions of issuers into Markit's Credit Default Swap spread database. We find large and statistically significant decreases in mark dispersion of newly disseminated bonds around key TRACE system rollout events. Dispersion for large, investment grade bonds fell $20 \%$ to $83 \%$ after the start of TRACE reporting. We also find evidence of spillover effects for non-disseminated bonds. During the pre-TRACE period, we find some evidence that mark dispersion fell for investment grade issuers after introductions into Markit's database. Our results provide support for the idea that the TRACE transparency initiative reduced information inequality within the institutional side of the market. The original NASD concern about people "operating largely in the dark" effectively applied to professional fund managers.
\end{abstract}

Keywords: TRACE, CDS, bonds, transparency, marks

Gjergi Cici is an Associate Professor at the Mason School of Business,

College of William and Mary, P.O. Box 8795, Williamsburg, VA 23187 and

Research Fellow at the Centre for Financial Research (CFR), University of

Cologne, Gjergji.Cici@mason.wm.edu, 757-221-1826

Scott Gibson is a Professor of Finance and J.E. Zollinger Term Professor at the Mason School of Business, College of William and Mary,

Scott.Gibson@mason.wm.edu, 757-221-1673

Yalin Gündüz is a Researcher at Deutsche Bundesbank, Banking and Financial Supervision Research, Wilhelm-Epstein-Straße 14, 60431

Frankfurt am Main, Germany, yalin.gunduz@bundesbank.de, 4969 95668163

John J. Merrick, Jr. is the Richard S. Reynolds Professor of Business at the Mason School of Business, College of William and Mary, John.Merrick@mason.wm.edu,757-221-2721 
The validity of the price marks placed on bonds for valuation purposes is important for a diverse group of stakeholders, including investors, mutual fund managers, dealers, pricing services, and financial regulators. For example, the price marks placed by some banks and hedge funds on certain bond and derivative positions became a controversial topic during the credit crisis that began in 2007 (e.g., see Financial Crisis Inquiry Commission, 2011). One very interested producer and consumer of bond marks is the mutual fund industry. The price marks on individual bonds held by a mutual fund help determine that fund's net asset value (NAV), which governs the terms by which the fund issues or redeems shares. Cici, Gibson, and Merrick [2011] find substantial crossfund dispersion in end-of-month marks placed by US corporate bond mutual fund managers on identical bonds. After controlling for differences related to choice of bid price or mid price marking standards, CGM show that cross-fund bond mark dispersion is higher for lower credit quality bonds, longer maturity bonds, and smaller issues. Mark dispersion also increases during periods when bond market return volatility is high.

In this paper, we investigate the reasons underlying CGM's additional finding that cross-fund bond mark dispersion declined during their 1998 to 2006 sample period. While a decline in mark dispersion may be consistent with a number of explanations, we examine the impacts of two special institutional developments during this particular period. First, the Financial Industry Regulatory Authority's (FINRA) predecessor organization, the National Association of Securities Dealers (NASD), rolled out the Trade Reporting and Compliance Engine (TRACE) system for collecting and disseminating corporate bond transaction details in phases starting July 1, 2002. Second, in support of the dramatic growth in trading of credit default swaps (CDS), Markit, the 
financial information services company, expanded its well-accepted database to provide paying subscribers with end-of-day indicative contract spreads for a wider set of individual issuers. Both of these institutional changes improved market transparency.

The NASD's clear goal in introducing TRACE was to increase price transparency in the US corporate debt market as per NASD Chairman and CEO Robert Glauber's statement: "This is far too important a sector to have people operating largely in the dark. Our aim is to provide quality information to the market about fixed income activity." The NASD's concern may have been directed towards relatively disadvantaged retail investors. ${ }^{2}$ Our research, however, does not concern retail investors. We examine whether "operating largely in the dark" applies to professional fund managers as well as the dealers and pricing services supporting them with valuation services.

Our investigation of whether TRACE reduced corporate bond mark dispersion highlights the information channel proposed by Bessembinder, Maxwell, and Venkataraman [2006]. In their world, increased valuation precision decreases both the inventory risks of market making and the likelihood that dealers can extract rents from less-well-informed counterparties. Their empirical estimates suggest that TRACE's introduction reduced trade execution costs by one-half, and that a spillover liquidity effect results in cost reductions even for non-eligible bonds.

Furthermore, a corporate bond of a given issuer can be valued via a theoretical arbitrage relationship with a CDS referencing this same issuer (Duffie [1999]). Markit's expansion of its CDS spread database to include additional issuers most likely benefitted subscribers (including dealers, pricing services, and mutual fund managers) in need of assessing current corporate bond values. Indeed, the NASD's Corporate Debt Market 
Panel opined in 2004 that those participants involved in both CDS and bonds may have had additional information available to them that could unfairly inform their trading decisions (NASD [2004]). Blanco, Brennan, and Marsh [2005] find that CDS lead corporate bonds in the price discovery process. The informational value of CDS database introductions most likely would have been especially valuable prior to the start of TRACE corporate bond trade dissemination.

We test whether initiations of TRACE trade reports and/or Markit database issuer introductions reduced cross-fund bond mark dispersion. Our first TRACE tests examine dispersion levels in tight six-month windows before and after three key TRACE rollout events. We find that bonds show economically and statistically significant decreases in mark dispersion after the dates their trade prices are first disseminated in TRACE. We also find evidence of concurrent decreases in mark dispersion for non-disseminated bonds, consistent with spillover effects via higher quality inputs to "matrix pricing" algorithms. A difference-in-differences regression test design applicable to the two-stage rollout of BBB-rated bonds as in Goldstein, Hotchkiss, and Sirri [2007] provides clearer evidence supporting this interpretation. Corresponding CDS tests examine dispersion levels in six-month windows before and after issuers first appeared in the Markit database. We find some evidence that, prior to the July 2002 inception of TRACE, bonds show decreases in mark dispersion when their issuers first appear in the Markit database. No such pattern exists after July 2002. This evidence suggests that the pricing information generated via TRACE bond transaction reporting encompasses any markrelevant information generated by CDS spreads. Taken altogether, our results provide support for the idea that the TRACE transparency initiative reduced information 
inequality within the institutional side of the market. Thus, the NASD's concern about people "operating largely in the dark" effectively applied to professional fund managers.

\section{Marking a bond}

A mutual fund faces securities pricing challenges every day when it produces its end-of-day NAV. Each security in its portfolio must be marked, even if some specific issues have not traded for days or even weeks. Most corporate bond issues trade in thin, illiquid over-the-counter dealer markets. Marking such securities is more difficult than, say, US Treasury securities and involves information collection and professional judgment.

Bond dealer firms and securities pricing services compile daily marks on individual issues. Dealers compile their own marks for internal profit and loss determination, repurchase agreement collateral valuation, bond index construction, and client servicing purposes. Within each firm, traders use available quotes from inter-dealer broker screens on the subject security or related securities, their own customer flows, and any available "market color" - stories behind the day's transactions relayed from a variety of sources - as inputs to the marking process. Furthermore, compliance and risk management professionals typically review the appropriateness of these marks, especially with regard to the integrity of internal daily profit and loss figures. ${ }^{3}$ Generally, buy-side customers that have multiple (say, five) dealer relationships can get effective best-in-class price knowledge for any bond through their dealer sources. ${ }^{4}$

Pricing services are for-profit firms that provide securities marks to customers like mutual funds for a fee. Pricing services compete for business along dimensions of pricing quality, security coverage, and data transmission reliability. These data cover both 
listed market prices for exchange-traded securities and "evaluated" prices for over-thecounter market securities. Pricing services produce an evaluated price for an over-thecounter market security using firm-specific matrix pricing methods that incorporate issuer and bond characteristics as well as available dealer quotes and observed prices for bonds and derivatives that do trade (Bessimbinder et al. [2006]).

The precision with which a typical high-yield corporate security can be mechanically marked off of liquid securities like Treasuries or liquid derivatives like Libor-based interest rate swaps may be low. Mutual funds have substantial discretion in marking bonds. A fund's traders, analysts and portfolio managers responsible for specific security positions routinely investigate and sometimes challenge a pricing service's mark for any particular security if that default price feed result appears unreasonable.

One likely reason that marks may differ across reporting funds is that the pricing information that the various pricing services and the funds themselves glean from alternative bond dealers differs across dealers. Because so many corporate bond issues are illiquid and infrequently traded, different dealers will experience different customer flows. Prior to TRACE transaction report dissemination, a dealer who had not recently traded a particular illiquid bond no doubt had a less informative opinion of its current value than another dealer who had freshly traded it with a counterparty. The actual transaction prices reported during the day after the start of TRACE disseminations should have generated useful new valuation information for many dealers and pricing services. Thus, the transmission mechanism for any TRACE-induced reductions in dispersion of bond marks across mutual funds most likely worked through reductions in the dispersion of marks on individual bonds across pricing services. We do not have the 
proprietary pricing service mark data necessary to examine this channel directly.

Indicative CDS spreads provide implicit market assessments of issuer default probability and bond recovery values. The CDS markets can be much more liquid than those for the underlying corporate bonds and therefore might better aggregate investor opinions to provide a timely corporate bond valuation signal. Both Forte and Pena [2009] and Norden and Weber [2009] confirm Blanco, Brennan, and Marsh's [2005] finding of a price discovery advantage of CDS markets over bond markets. Ashcraft and Santos [2009] study the impact of CDS contract trading initiations on issuance yield spreads of corporate bonds and syndicated loans. They find evidence of a small reduction in the spreads that safer and more transparent firms pay to borrow in both the bond market and from banks after initiations of CDS trading. In contrast, they also find that CDS trading initiations have increased the cost of debt financing for the riskier firms as well as those that are more opaque.

Finally, Bessembinder and Maxwell [2008] suggest that while TRACE transparency reduced the cost of trading corporate bonds, it also reduced the quality and quantity of the services provided by bond dealers. Tempelman [2009] asserts that any TRACE facilitation of price discovery has been at the expense of quantity discovery and has incrementally decreased bond market liquidity. Das, Kalimipalli, and Nayak [2014] suggest that TRACE-induced reductions in dealer market-making activity incentivized large customers to move business to CDS markets. They find that initiation of CDS trading causes deterioration in corporate bond market efficiency without any associated improvements in bond market quality or liquidity. 


\section{Data}

We combine data from Morningstar, Mergent FISD, FINRA, and Markit. The Morningstar mutual fund holdings database contains the market value, par value, and Committee on Uniform Security Identification Procedures (CUSIP) identifier of each security held by each mutual fund on each report date. Both surviving and dead funds are available in the database. We obtain historical bond issue-specific characteristics such as credit ratings, coupon rates, maturity dates, and issue sizes from Mergent FISD and match these data via bond CUSIPs with Morningstar holdings data beginning in 1995 . FINRA provided additional data on TRACE dissemination dates.

We follow CGM and calculate a full or "dirty" price for every bond holding as the ratio of market value to par value on each bond held by each fund. ${ }^{5}$ We measure bond mark dispersion as the interquartile range (IR), the difference between the 75 th and 25 th percentiles in the distribution of these price marks for the set of funds that hold a given bond on a particular month-end date. For a bond to be included in the sample, three or more funds must report the price of the identical bond as of the same date. By law, funds must submit holdings reports to the Securities and Exchange Commission every fiscal quarter. Nevertheless, we construct a monthly mark dispersion data series because fund fiscal year ends are spread throughout the year and because some funds voluntarily report holdings to Morningstar on a monthly basis. As in CGM, we calculate dispersion separately for all bond mutual funds, mid-marking funds, and bid-marking funds. ${ }^{6}$

We obtain historical data on issuers with CDS contracts from Markit for the period between 2001 and 2006. Markit manages and distributes a widely used CDS spread database that provides users with end-of-day consensus pricing on single-name 
CDS. Markit collects CDS curve submissions on a daily basis directly from more than 30 contributing sell-side dealers. After removing outliers and stale observations, Markit generates a daily composite spread curve for a given entity, capital structure tier, maturity, currency, and restructuring type. To calculate a consensus spread curve for an issuer, Markit requires that at least three contributors submit their CDS curves, of which at least two should pass all data cleaning tests (Markit [2011]). Thus, the first observable indicative spread for an entity in the Markit database is an indication of that entity having a liquid CDS. Markit's data has been widely utilized (e.g., Acharya and Johnson [2007]; Jorion and Zhang [2007]; and Zhang, Zhou, and Zhu [2009]).

Ashcraft and Santos [2009] and Ismailescu and Phillips [2012] also use Markit database introductions on 5-year CDS contracts to date CSD trading initiations. We expand that dating methodology here by using all maturities to capture any case that, say, a 3-year or 10-year contract was introduced prior to the 5-year maturity contract.

\section{TRACE and mark dispersion}

On July 1, 2002, dissemination of individual TRACE corporate bond transaction details incorporating issue identity, execution date and time, price, and trade size information began for all investment grade bonds with original issue sizes greater than $\$ 1$ billion as well as for a select set of 50 high yield bonds. On March 3, 2003, dissemination began for all investment grade bonds rated $\mathrm{A}$ or higher with original issue sizes of at least $\$ 100$ million. Dissemination of BBB-rated issues with an original issue size less than $\$ 1$ billion occurred in two phases. On April 14, 2003, dissemination began for a select set of 120 BBB bonds. On October 1, 2004, dissemination began for the remaining BBB bonds and high yield bonds. ${ }^{7}$ 
Exhibit 1 presents results of tests for shifts in mark dispersion across six-month data windows before and after the TRACE system's key rollout ("event") dates. Panels A.1 and A.2 present results of tests using July 2002 as the event month. Panel B presents results for an event period split prior to March 2003 and after April 2003. Panel C presents results of tests using October 2004 as the event month. We test the hypothesis that mean dispersion decreased across the six-month windows after each TRACE event based upon a one-sided t-test. Within each panel, groups in boldfaced type are being disseminated on the event date under study. Groups in italicized boldfaced type have not yet been disseminated, but share the credit rating and size category of other bonds being disseminated for the first time on the event date under study.

Panel A.1 in Exhibit 1 shows the impacts of dispersion associated with dissemination of largest ( $\$ 1$ billion+) investment grade and 50 select high yield bonds. The results indicate that the large investment grade bonds experienced economically and statistically significant decreases in dispersion after their key July 2002 dissemination start date (t-values are all greater than the $1 \%$ significance level one-sided test critical value of 2.32). For example, the dispersion of these bonds fell by .089, from .366 to .277 , representing a 24\% drop across the July 2002 dissemination start date. The corresponding drops for the bid-markers and mid-markers samples were $.063(21 \%)$ and $.103(29 \%)$, respectively. We could not analyze the set of 50 initially disseminated high-yield bonds since none of these bonds were held by at least three funds both in the pre- and post-event window. But dispersions of the non-disseminated high yield bonds fell by $.074(10 \%)$, $.13(23 \%)$, and $.103(19 \%)$ across this July 2002 date. These drops are also statistically significant at the $1 \%$ level. Note that these drops in dispersion occur even though there 
was no corresponding statistically significant shift in investment grade bond market return volatility.

The dispersion decrease for non-disseminated high yield bonds is consistent with a spillover effect from the 50-issue subset of high-yield bonds, mirroring the results of Bessembinder, Maxwell, and Venkataraman [2006]. These results hold for dispersion measured based on samples of all funds, only bid-marking funds, and only mid-marking funds. Large, high quality ( $\$ 100$ million+; A-rated or better), the 120 select BBB bonds, and the other BBB bonds also show a decrease in dispersion for the all-fund sample, but the decreases are statistically insignificant. Results are mixed for these bonds when bidmarking and mid-marking funds are analyzed separately. The tests for the 120 select BBB bonds are based on much smaller sample sizes.

\section{Insert Exhibit 1 about here}

Panel A.2 presents results from tests that allow for a three-month transition for funds and pricing services to adapt methodologies to incorporate TRACE reports. A lessthan-full immediate response by pricing analysts to TRACE might be expected given the licensing, technical, and practical issues related to accessing and integrating the raw TRACE data feeds on thousands of individual corporate bonds. The tests in Panel A.2 examine the joint hypothesis that TRACE's impact was only fully reflected after a threemonth transition period. Under our test design, the transition period applies only to the first event (July 2002) since the lessons learned and systems created to handle TRACE at that date could be immediately applied to the later TRACE rollout events.

The results in Panel A.2 suggest that the transition period approach may be a useful description of the way TRACE affected bond-pricing precision. The dispersion 
declines summarized in Panel A.2 tend to be economically and statistically significant and larger in magnitude than those from Panel A.1. Across this July 2002 date, the dispersions of the largest investment grade for our all funds, bid-marking funds, and midmarking funds samples fell by $.187(52 \%), .249(83 \%)$, and $.103(40 \%)$, respectively. The dispersion decreases for the other bond groups tend to suggest economically and statistically important spillover effects. These drops in dispersion occur even though there was no corresponding statistically significant shift in bond market return volatility.

Panel B shows that both large, high quality and the 120 select BBB bonds experienced economically and statistically significant decreases in dispersion for the allfund sample after their April 2002 initial dissemination. These drops in dispersion occur despite a corresponding statistically significant increase in bond market return volatility. The result is statistically weaker for bid- and mid-marking funds. We also find evidence of decreased dispersion for the other bonds, again consistent with a spillover effect or continued refinement in the use of TRACE information by the pricing services.

Finally, Panel C reports results for an event window centered on October 2004. The results reveal more muted changes in dispersion, perhaps due to the fact that most of the bond universe had already been disseminated in TRACE for some time. Only the all other BBB bonds show some evidence of a dispersion decrease after October 2004 (the date when their prices began being disseminated). However, these results should be interpreted with caution given the statistically significant coincident decline in volatility.

The coefficient point estimates from the boldfaced rows (i.e., the bond groups being disseminated on the event date under study) tend to indicate that dispersion impacts are largest and most statistically significant. For example, consider the July 1, 2002 
rollout of the largest ( $\$ 1$ billion+) investment grade and 50 select high yield bonds reported in Panel A.1. The estimated drop in all funds' dispersion for the largest $(\$ 1$ billion+) investment grade bonds of $.089(24 \%)$ is large in both absolute and percentage terms and statistically significant at the $1 \%$ level. The estimated drop in all funds' dispersion for the all other high yield bond group of $.074(10.1 \%)$ is also large and statistically significant. The estimated drops in all funds' dispersion for the three other bond groups are not statistically significant. The ordering of these effects is in line with the intuition that the bonds being disseminated should be affected most (the largest investment grade bonds), followed by bonds related to groups being disseminated (all other high yield bonds via the 50 select high yield bond group), and trailed by bonds with the least direct ties to the disseminated groups (large, high quality and both BBB groups).

The results from Panel B tests for event windows around the March 3, 2003-April 14, 2003 period that defines the dissemination of large, high quality and the 120 select BBB bond groups show a similar pattern for the disseminated groups. The point estimates for the drops in dispersion of these disseminated groups are large in both absolute and percentage terms and statistically significant at conventional levels. The Panel $\mathrm{C}$ results for the all other high yield bonds group do not conform to the expected pattern.

Goldstein et al. [2007] emphasize that the two-stage rollout of BBB bonds permits a difference-in-differences research design for testing TRACE dissemination effects across the April 14, 2003 event date. This is the only event in the TRACE rollout that can be analyzed using a difference-in-differences approach. Exhibit 2 presents results from difference-in-differences regressions for these BBB bonds. The dependent variable is the cross-fund bond mark interquartile range. The zero/one indicator variable 120 
Select Bonds allows the mean dispersion value for the 120 select BBB bond group to differ from that of the remaining BBB bonds. The zero/one indicator variable Post-April 13, 2003 allows the mean dispersion value for all bonds over the post-April 14, 2003 period to differ from that for the pre-April 14, 2003 period. The regressions also include controls for Issue Size, the log of the original par value of the bond issue expressed in millions of dollars; Maturity, the remaining time to maturity of the bond expressed in years; Age, the time elapsed since the bond's issuance expressed in years; and Volatility, the annualized standard deviation of daily percentage returns for the Barclays Investment Grade Bond Index during the concurrent observation month.

The final two variables concern the impact of TRACE on dispersion. The first is the Goldstein et al. [2007] Sibling, which equals one for each bond where another of the same issuer's bonds had been disseminated in TRACE prior to April 14, 2003 and zero otherwise. The second is the interaction term 120 Select Bonds * Post-April 13, 2003. Sibling allows us to quantify an indirect TRACE-related impact on mark dispersion. The interaction term 120 Select Bonds * Post-April 13, 2003 identifies a change in dispersion for the 120 select $\mathrm{BBB}$ bonds relative to that for the non-disseminated $\mathrm{BBB}$ bonds.

\section{Insert Exhibit 2 about here}

The first column in Exhibit 2 reports estimates using all data for the January 1995 to September 2004 period. The second column reports estimates for the same sample used in the tests in Panel B of Exhibit 1 (i.e., combining the six-month windows around either side of the March-April 2003 event). The estimates from both samples yield similar conclusions. First, the negative estimated coefficients for Sibling is evidence that prior TRACE dissemination of a bond of the same issuer is associated with a 5.0 to 8.0 cents 
lower price dispersion for all of the issuer's bonds. This indirect TRACE effect is statistically significant at standard levels. ${ }^{8}$ Second, the negative estimated coefficients on the 120 Select Bonds * Post-April 13, 2003 suggests that dispersion for the 120 select bonds group fell 6.0 to 10.0 cents relative to the non-disseminated BBB bonds via a direct TRACE dissemination impact. This direct dissemination effect is statistically significant at the 5\% level for a one-sided test in the first sample, but lacks significance in the second sample. In the main, our findings are consistent with the view that the transparency-enhancing TRACE system contributed to a decrease in mark dispersion, including spillover effects on non-disseminated bonds.

\section{CDS trading and mark dispersion}

Exhibit 3 plots two measures designed to track the growth of CDS market activity over the 2001 to 2006 sample period: the total outstanding notional par value of CDS contracts estimated by the International Swaps and Derivatives Association via biannual member surveys and the number of issuers listed in the Markit CDS spread database. The outstanding notional par value of CDS contracts roughly doubled each year over the fiveyear period from December 2001 to December 2006 to a total of nearly $\$ 35$ trillion. The number of Markit issuers grew fastest in the first half of the period (about 70\% per year) and then decelerated sharply beginning in 2004.

\section{Insert Exhibit 3 about here}

Exhibit 4 reports summary statistics comparing characteristics of issuers based upon their Markit database status. Each month, we categorize issuers based upon whether or not they were included in the Markit indicative CDS spread database at that time. Characteristics were averaged across all issuers belonging to each category every month 
to create a time series for characteristics of both groups. CDS trading is associated with entities issuing larger bonds, higher credit quality bonds, and longer maturity bonds.

\section{Insert Exhibit 4 about here}

Exhibit 5 presents tests investigating whether the expansion of CDS trading was associated with shifts in bond mark dispersion for three issuer groups based upon credit rating (all issuers, only investment grade issuers, and only high yield issuers) for each of our three fund marking categories (all funds, only bid-marking funds, and only midmarking funds). Panel A compares bond mark dispersion in six-month windows before and after the date that Markit first releases an issuer's CDS contract spread data. Regardless of the sample studied, we find no statistically significant changes in mark dispersion for bonds in the period surrounding the issuer's first appearance in Markit. Note that, using Hasbrouck's [1993] pricing accuracy measure, Das et al. [2014] find no significant improvement in market quality after initiations of CDS trading.

\section{Insert Exhibit 5 about here}

The results from Panel A incorporate Markit database issuer introductions occurring both before and after the July 1, 2002 start of the TRACE system rollout. It may be possible that indicative CDS spreads do provide useful information for marking bonds, but that such information adds little value to the direct trade report data available from TRACE. Panel B examines just those issuer introductions occurring in the preTRACE period. For the all funds sample, mark dispersion for the all issuers group falls by 5.0 cents on average (significant at the $5 \%$ level) when an issuer first appears in Markit. Corresponding results for bid- and mid-marking funds show decreases in dispersion of similar size that lack statistical significance at conventional levels. 
The pre-TRACE period results for investment grade issuers amplify those found using data for all issuers. The estimated drop in mark dispersion is larger and more statistically significant for the all funds and bid-marking samples. However, corresponding results for high yield issuers show negligible declines in dispersion that are not statistically significant regardless of fund category. These perhaps curious results for high yield issuers echo those of Ashcraft and Santos [2009], who find that CDS initiations raised issuance spreads for riskier, more opaque firms. For completeness, we also examined whether the change in price dispersion around TRACE initial dissemination dates differs for bonds of issuers who appear in Markit's CDS spread database. Unreported results show insignificant differences between the pricing dispersion changes for the two subgroups of the BBB rollout. ${ }^{9}$

\section{Conclusions}

Our evidence suggests that the transparency-enhancing TRACE system was associated with large and statistically significant decreases in cross-fund bond mark dispersion. We find some evidence that issuer initiations into Markit's CDS spread database also contributed to a decrease in bond mark dispersion, but only during the preTRACE era. These results support the view that the NASD's original stated concern about people "operating largely in the dark" applied to not just retail investors, but also to professional fund managers. Although we offer no fund-level evidence, our results imply that TRACE has led to more uniform mutual fund NAV calculations.

The TRACE-associated decline in bond valuation dispersion provides indirect empirical support for Bessembinder et al.'s [2006] channel relating increased transparency and pricing. Nevertheless, Das et al. [2014] suggest that TRACE-enhanced 
transparency may have reduced market-making activity, moved business to CDS markets, and caused corporate bond market efficiency to deteriorate. Das et al. [2014] also find no evidence that CDS trading improves market quality as measured by price accuracy. For the bond marks used by mutual fund managers, we find that the information generated by the CDS market appears redundant given TRACE bond trade report transparency.

\section{REFERENCES}

Acharya, V. and T. Johnson. "Insider Trading in Credit Derivatives." Journal of Financial Economics, 84 (2007), pp. 110-141.

Ashcraft, A.B., and J.A.C. Santos. "Has the CDS Market Lowered the Cost of Corporate Debt?” Journal of Monetary Economics, Vol. 56, No. 4 (2009), pp. 514-523.

Bessembinder, H., and W. Maxwell. "Transparency and the Corporate Bond Market." Journal of Economic Perspectives, Vol. 22, No. 2 (2008), pp. 217-234.

Bessembinder, H., W. Maxwell, and K. Venkataraman. "Market Transparency, Liquidity Externalities, and Institutional Trading Costs in Corporate Bonds." Journal of Financial Economics, Vol. 82, No. 2 (2006), pp. 251-288.

Blanco, R., S. Brennan, and I. Marsh. "An Empirical Analysis of the Dynamic Relation Between Investment-grade Bonds and Credit Default Swaps." Journal of Finance, 60 (2005), pp. 2255-2281.

Bond Market Association and The American Securitization Forum. "An Analysis and Description of Pricing and Information Sources in the Securitized and Structured Finance Markets," October (2006).

Cici, G., S. Gibson, and J. Merrick. "Missing the Marks? Dispersion in Corporate Bond Valuations Across Mutual Funds." Journal of Financial Economics, Vol. 101, No. 1 (2011), pp. 206-226.

Das, Sanjiv, M. Kalimipalli, and S. Nayak. "Did CDS Trading Improve the Market for Corporate Bonds?” Journal of Financial Economics, Vol. 111, No. 2 (2014), pp. 495-525.

Duffie, D. “Credit Swap Valuation.” Financial Analysts Journal, 55 (1999), pp. 73-87.

Edwards, A., L. Harris, and M. Piwowar. "Corporate Bond Market Transparency and Transaction Costs.” Journal of Finance, Vol. 62, No. 3 (2007), pp. 1421-1451. 
Financial Crisis Inquiry Commission, Final Report of the National Commission on the Causes of the Financial and Economic Crisis in the United States, Government Printing Office: Washington, January 2001.

Forte, S., and J. Pena. "Credit Spreads: An Empirical Analysis on the Informational Content of Stocks, Bonds, and CDS.” Journal of Banking and Finance, 33 (2009), pp. 2013-2025.

Glauber, R. Remarks at the Securities Industry Association's Market Structure Conference on June 7, 2002. http://www.finra.org/Newsroom/Speeches/Glauber/P011002.

Goldstein, M., E. Hotchkiss, and E. Sirri. "Transparency and Liquidity: A Controlled Experiment on Corporate Bonds." Review of Financial Studies, Vol. 20, No. 2 (2007), pp. 235-273.

Hasbrouck, J., "Assessing the Quality of a Security Market: A New Approach to Transaction-cost Measurement.” Review of Financial Studies, 6 (1993), pp. 191-212.

Ismailescu, I., and B. Phillips. "Savior or Sinner?" Credit Default Swaps and the Market for Sovereign Debt.” Unpublished working paper, 2012.

Jorion, P., and G. Zhang. "Good and Bad Credit Contagion: Evidence from Credit Default Swaps.” Journal of Financial Economics, 84 (2007), pp. 860-883.

Markit. “CDS Data Cleaning Process.” White paper, November 2011.

NASD, Report of the Corporate Debt Market Panel, Washington, September, 2004.

Norden, L., and M. Weber. "The Co-movement of Credit Default Swap, Bond and Stock Markets: An Empirical Analysis.” European Financial Management, 15 (2009), pp. 529562.

Pulliam, S., "Bonds' Pricing is Questioned in Email Trail," The Wall Street Journal, October 26, 2007, C1.

Rogers, W. "Regression Standard Errors in Clustered Samples." Stata Technical Bulletin 13 (1993), pp. 19-23.

Tempelman, J. "Price Transparency in the US Corporate Bond Markets." The Journal of Portfolio Management, Vol. 35, No. 3 (2009), pp. 27-33.

Zhang, B. Y., H. Zhou, and H. Zhu. "Explaining Credit Default Swap Spreads with the Equity Volatility and Jump Risks of Individual Firms." Review of Financial Studies, 22 (2009), pp. 5099-5131. 


\section{Exhibit 1}

\section{Dispersion comparison before and after TRACE dissemination dates}

This table reports the interquartile range of the bond prices reported by mutual funds for alternative bond groups for pre- and post-TRACE event data windows. The first data window includes all observations in the six months prior to the event date or event period. The second window includes all observation in the six months subsequent to the event date or event period. We could not separate the set of 50 initially disseminated high yield bonds since none of these bonds were held by at least three funds in both the pre- and post-event windows. Thus, the " 50 select high yield bonds" group does not appear in the table. Dispersion is calculated separately for all bond mutual funds, mid-marking funds, and bid-marking funds. We aggregate any multiple observations for the same bond in each of the windows by averaging their corresponding dispersion measures. Volatility is the annualized monthly standard deviation of daily percentage returns for the Barclays US Corporate Investment Grade Bond Index. N refers to the number of bonds in each sample. Statistics for the differences in dispersion between the two windows (presented in parentheses) are based on a paired t-test interpreted using one-sided test statistic critical values of 2.32 (1\% significance level), $1.65(5 \%)$, and 1.28 (10\%). Within each panel, groups in boldfaced type are being disseminated on the event date under study. Groups in italicized boldfaced type have not yet been disseminated but share the credit rating and size category of other bonds being disseminated for the first time on the event date under study.

\begin{tabular}{|c|c|c|c|c|c|c|c|c|c|c|c|c|c|c|c|}
\hline \multicolumn{16}{|c|}{ Panel A. Comparisons of dispersion measures when TRACE was first introduced } \\
\hline \multirow[t]{3}{*}{ Panel A.1 Event windows around July 1, 2002 dissem } & on of $L$ & $\operatorname{argest}(\$$ & billion- & Investm & \multirow[b]{3}{*}{$\%$ Change } & 0 Selec & et High Y & eld bond & & & & & & & \\
\hline & \multicolumn{4}{|c|}{ All Funds' Prices } & & \multicolumn{5}{|c|}{ Bid Markers' Prices } & \multicolumn{4}{|c|}{ Mid Markers' Prices } & \multirow[b]{2}{*}{$\%$ Change } \\
\hline & $\mathrm{N}$ & Before & After & Diff & & $\mathrm{N}$ & Before & After & Diff & $\%$ Change & $\mathrm{N}$ & Before & After & Diff & \\
\hline Largest (\$1 billion+) Investment Grade & 219 & 0.366 & 0.277 & $\begin{array}{c}-0.089 \\
(-2.94)\end{array}$ & $-24.3 \%$ & 190 & 0.306 & 0.244 & $\begin{array}{l}-0.063 \\
(-2.93)\end{array}$ & $-20.6 \%$ & 173 & 0.351 & 0.249 & $\begin{array}{c}-0.103 \\
(-2.36)\end{array}$ & $-29.3 \%$ \\
\hline Large, High Quality ( $\$ 100$ million+; A-rated or better) & 996 & 0.531 & 0.509 & $\begin{array}{l}-0.022 \\
(-0.91)\end{array}$ & $-4.1 \%$ & 334 & 0.375 & 0.302 & $\begin{array}{l}-0.073 \\
(-2.42)\end{array}$ & $-19.5 \%$ & 211 & 0.333 & 0.398 & $\begin{array}{r}0.066 \\
(1.22)\end{array}$ & $19.8 \%$ \\
\hline 120 Select BBB bonds & 59 & 0.646 & 0.576 & $\begin{array}{l}-0.070 \\
(-0.67)\end{array}$ & $-10.8 \%$ & 33 & 0.385 & 0.456 & $\begin{array}{c}0.071 \\
(0.64)\end{array}$ & $18.4 \%$ & 20 & 0.366 & 0.433 & $\begin{array}{l}0.067 \\
(0.52)\end{array}$ & $18.3 \%$ \\
\hline All other BBB bonds & 834 & 0.571 & 0.518 & $\begin{array}{l}-0.053 \\
(-1.61)\end{array}$ & $-9.3 \%$ & 382 & 0.457 & 0.337 & $\begin{array}{l}-0.119 \\
(-3.20)\end{array}$ & $-26.0 \%$ & 292 & 0.467 & 0.378 & $\begin{array}{l}-0.089 \\
(-1.66)\end{array}$ & $-19.1 \%$ \\
\hline All other High Yield bonds & 1475 & 0.731 & 0.656 & $\begin{array}{l}-0.074 \\
(-2.87)\end{array}$ & $-10.1 \%$ & 777 & 0.559 & 0.429 & $\begin{array}{l}-0.130 \\
(-4.50)\end{array}$ & $-23.3 \%$ & 1017 & 0.537 & 0.433 & $\begin{array}{l}-0.103 \\
(-3.42)\end{array}$ & $-19.2 \%$ \\
\hline Investment Grade Bond Index Volatility & & 4.40 & 5.42 & $\begin{array}{r}1.02 \\
(1.74) \\
\end{array}$ & $23.2 \%$ & & & & & & & & & & \\
\hline Largest ( $\$ 1$ billion+) Investment Grade & 218 & 0.362 & 0.174 & $\begin{array}{c}-0.187 \\
(-6.07)\end{array}$ & $-51.7 \%$ & 189 & 0.301 & 0.052 & $\begin{array}{r}-0.249 \\
(-11.18)\end{array}$ & $-82.7 \%$ & 170 & 0.352 & 0.210 & $\begin{array}{c}-0.142 \\
(-3.48)\end{array}$ & $-40.3 \%$ \\
\hline Large, High Quality ( $\$ 100$ million+; A-rated or better) & 928 & 0.533 & 0.372 & $\begin{array}{l}-0.160 \\
(-6.39)\end{array}$ & $-30.0 \%$ & 317 & 0.369 & 0.211 & $\begin{array}{l}-0.157 \\
(-4.33)\end{array}$ & $-42.5 \%$ & 188 & 0.321 & 0.349 & $\begin{array}{l}0.028 \\
(0.42)\end{array}$ & $8.7 \%$ \\
\hline 120 Select BBB bonds & 58 & 0.659 & 0.421 & $\begin{array}{l}-0.238 \\
(-2.20)\end{array}$ & $-36.1 \%$ & 31 & 0.367 & 0.337 & $\begin{array}{l}-0.030 \\
(-0.22)\end{array}$ & $-8.2 \%$ & 19 & 0.382 & 0.213 & $\begin{array}{l}-0.169 \\
(-1.33)\end{array}$ & $-44.2 \%$ \\
\hline All other BBB bonds & 748 & 0.579 & 0.320 & $\begin{array}{l}-0.259 \\
(-7.44)\end{array}$ & $-44.7 \%$ & 355 & 0.462 & 0.187 & $\begin{array}{l}-0.275 \\
(-7.51)\end{array}$ & $-59.5 \%$ & 259 & 0.497 & 0.354 & $\begin{array}{l}-0.143 \\
(-2.18)\end{array}$ & $-28.8 \%$ \\
\hline All other High Yield bonds & 1418 & 0.726 & 0.551 & $\begin{array}{l}-0.175 \\
(-6.49)\end{array}$ & $-24.1 \%$ & 741 & 0.562 & 0.330 & $\begin{array}{l}-0.231 \\
(-7.55)\end{array}$ & $-41.1 \%$ & 968 & 0.505 & 0.360 & $\begin{array}{l}-0.146 \\
(-4.71)\end{array}$ & $-28.9 \%$ \\
\hline Investment Grade Bond Index Volatility & & 4.40 & 4.78 & $\begin{array}{r}0.38 \\
(0.72)\end{array}$ & $8.6 \%$ & & & & & & & & & & \\
\hline
\end{tabular}




\section{Exhibit 1 - continued}

Panel B. Event windows around the March 1, 2003-April 14, 2003 period dissemination of Large, High Quality and 120 Select BBB bonds

\begin{tabular}{|c|c|c|c|c|c|c|c|c|c|c|c|c|c|c|c|}
\hline \multirow[b]{2}{*}{ Bond Groups } & \multicolumn{4}{|c|}{ All Funds' Prices } & \multirow[b]{2}{*}{$\%$ Change } & \multicolumn{5}{|c|}{ Bid Markers' Prices } & \multicolumn{4}{|c|}{ Mid Markers' Prices } & \multirow[b]{2}{*}{$\%$ Change } \\
\hline & $\mathrm{N}$ & Before & After & Diff & & $\mathrm{N}$ & Before & After & Diff & $\%$ Change & $\mathrm{N}$ & Before & After & Diff & \\
\hline \multirow[t]{2}{*}{ Largest ( $\$ 1$ billion+) Investment Grade } & 238 & 0.244 & 0.181 & -0.063 & $-25.8 \%$ & 213 & 0.171 & 0.131 & -0.040 & $-23.4 \%$ & 184 & 0.224 & 0.186 & -0.038 & $-17.0 \%$ \\
\hline & & & & $(-4.07)$ & & & & & $(-2.32)$ & & & & & $(-1.79)$ & \\
\hline \multirow[t]{2}{*}{ Large, High Quality ( $\$ 100$ million+; A-rated or better) } & 1067 & 0.472 & 0.349 & -0.122 & $-25.8 \%$ & 401 & 0.278 & 0.239 & -0.038 & $-13.7 \%$ & 277 & 0.280 & 0.222 & -0.057 & $-20.4 \%$ \\
\hline & & & & $(-5.32)$ & & & & & $(-1.56)$ & & & & & $(-1.87)$ & \\
\hline \multirow[t]{2}{*}{120 Select BBB bonds } & 59 & 0.505 & 0.313 & -0.192 & $-38.0 \%$ & 38 & 0.528 & 0.239 & -0.289 & $-54.7 \%$ & 26 & 0.386 & 0.191 & -0.195 & $-50.5 \%$ \\
\hline & & & & $(-2.70)$ & & & & & $(-1.60)$ & & & & & $(-1.76)$ & \\
\hline \multirow[t]{2}{*}{ All other BBB bonds } & 807 & 0.436 & 0.344 & -0.093 & $-21.3 \%$ & 429 & 0.298 & 0.224 & -0.074 & $-24.8 \%$ & 347 & 0.311 & 0.286 & -0.024 & $-7.7 \%$ \\
\hline & & & & $(-3.25)$ & & & & & $(-2.32)$ & & & & & $(-0.61)$ & \\
\hline \multirow[t]{2}{*}{ All other High Yield bonds } & 1375 & 0.608 & 0.521 & -0.088 & $-14.5 \%$ & 814 & 0.388 & 0.317 & -0.072 & $-18.6 \%$ & 1012 & 0.352 & 0.374 & 0.022 & $6.3 \%$ \\
\hline & & & & $(-4.15)$ & & & & & $(-2.95)$ & & & & & (1.07) & \\
\hline Investment Grade Bond Index Volatility & & 4.99 & 5.84 & $\begin{array}{r}0.85 \\
(1.34)\end{array}$ & $17.0 \%$ & & & & & & & & & & \\
\hline
\end{tabular}

Panel C. Event windows around October 1, 2004 dissemination of all other Investment Grade and High Yield bonds

\begin{tabular}{|c|c|c|c|c|c|c|c|c|c|c|c|c|c|c|c|}
\hline \multirow[b]{2}{*}{ Bond Groups } & \multicolumn{4}{|c|}{ All Funds' Prices } & \multirow[b]{2}{*}{$\%$ Change } & \multicolumn{5}{|c|}{ Bid Markers' Prices } & \multicolumn{4}{|c|}{ Mid Markers' Prices } & \multirow[b]{2}{*}{$\%$ Change } \\
\hline & $\mathrm{N}$ & Before & After & Diff & & $\mathrm{N}$ & Before & After & Diff & $\%$ Change & $\mathrm{N}$ & Before & After & Diff & \\
\hline Largest $(\$ 1$ billion + ) Investment Grade & 271 & 0.115 & 0.133 & $\begin{array}{l}0.018 \\
(1.30)\end{array}$ & $15.7 \%$ & 223 & 0.045 & 0.046 & $\begin{array}{c}0.001 \\
(0.11)\end{array}$ & $2.2 \%$ & 215 & 0.151 & 0.125 & $\begin{array}{l}-0.026 \\
(-2.14)\end{array}$ & $-17.2 \%$ \\
\hline Large, High Quality ( $\$ 100$ million+; A-rated or better) & 1164 & 0.225 & 0.219 & $\begin{array}{l}-0.006 \\
(-0.45)\end{array}$ & $-2.7 \%$ & 401 & 0.089 & 0.089 & $\begin{array}{r}0.000 \\
(-0.00)\end{array}$ & $0.0 \%$ & 345 & 0.165 & 0.123 & $\begin{array}{l}-0.042 \\
(-2.13)\end{array}$ & $-25.5 \%$ \\
\hline 120 Select BBB bonds & 56 & 0.218 & 0.212 & $\begin{array}{l}-0.006 \\
(-0.11)\end{array}$ & $-2.8 \%$ & 29 & 0.139 & 0.107 & $\begin{array}{l}-0.032 \\
(-0.99)\end{array}$ & $-23.0 \%$ & 20 & 0.151 & 0.146 & $\begin{array}{c}-0.004 \\
(-0.13)\end{array}$ & $-2.6 \%$ \\
\hline All other BBB bonds & 942 & 0.233 & 0.206 & $\begin{array}{l}-0.026 \\
(-2.43)\end{array}$ & $-11.2 \%$ & 490 & 0.134 & 0.104 & $\begin{array}{r}-0.030 \\
(-2.43)\end{array}$ & $-22.4 \%$ & 413 & 0.196 & 0.172 & $\begin{array}{r}-0.025 \\
(-1.54)\end{array}$ & $-12.8 \%$ \\
\hline All other High Yield bonds & 1431 & 0.455 & 0.459 & $\begin{array}{r}0.003 \\
(0.31)\end{array}$ & $0.7 \%$ & 1,061 & 0.312 & 0.325 & $\begin{array}{r}0.014 \\
(0.88)\end{array}$ & $4.5 \%$ & 1149 & 0.230 & 0.249 & $\begin{array}{r}0.019 \\
(2.08)\end{array}$ & $8.3 \%$ \\
\hline Investment Grade Bond Index Volatility & & 4.85 & 3.81 & $\begin{array}{r}-1.04 \\
(-3.09)\end{array}$ & $-21.4 \%$ & & & & & & & & & & \\
\hline
\end{tabular}




\section{Exhibit 2}

\section{Pooled regressions of price dispersion based upon the BBB-bond "natural experiment"}

This table reports results from pooled regressions of price dispersion for a set of BBB bonds on several control variables and certain dummy variables created to capture the impact of TRACE as motivated by Goldstein, Hotchkiss and Sirri (2007). Dispersion is measured as the interquartile range of prices reported by all mutual funds that reported ownership of a particular bond at a particular date. Only bond-date observations where the bond is held by at least three mutual funds are included. Observations include all BBB bonds with issue size less than $\$ 1$ billion and greater than $\$ 10$ million identified during a screening period from July 8, 2002 to January 31, 2003 as in Goldstein et al. (2007). Of this set of BBB bonds, 120 were disseminated by TRACE beginning April 14, 2003 ("120 Select Bonds"). Results in Column 1 use data for the January 1995-September 2004 period. Results in Column 2 use data only from the six-month windows around the March 1, 2003-April 14, 2003 period. T-statistics, presented in parentheses, are based on Rogers [1993] standard errors clustered by bond and period.

Explanatory Variables

Intercept

120 Select Bonds (equals one for each of the 120 BBB bonds disseminated on April 14, 2003 and zero otherwise)

Post-April 13, 2003 (equals one for observations after April 13, 2003

and zero otherwise)

Issue Size (log of the original face value of bond issue in \$millions)

Maturity (time until bond maturity date expressed in years)

Age (time since bond issue date expressed in years)

Volatility (annualized standard deviation of daily percentage price changes in the Barclays US Corporate Investment Grade Index)

Sibling (equals one for each bond where another of the same issuer's bonds was disseminated in TRACE prior to April 14, 2003 and zero otherwise)

120 Select Bonds * Post-April 13, 2003

$\mathrm{R}^{2}$

Observations

\begin{tabular}{|c|c|}
\hline $\begin{array}{r}\text { All months } \\
\text { January 1995- } \\
\text { September } 2004 \\
\end{array}$ & $\begin{array}{r}\text { 6-month windows } \\
\text { around March/April } \\
2003 \text { period }\end{array}$ \\
\hline $\begin{array}{l}0.304 \\
(1.73)\end{array}$ & $\begin{array}{l}0.037 \\
(0.17)\end{array}$ \\
\hline $\begin{array}{l}0.088 \\
(1.68)\end{array}$ & $\begin{array}{l}0.025 \\
(0.41)\end{array}$ \\
\hline $\begin{array}{l}-0.282 \\
(-7.15)\end{array}$ & $\begin{array}{l}-0.127 \\
(-1.22)\end{array}$ \\
\hline $\begin{array}{r}-0.016 \\
(-0.64)\end{array}$ & $\begin{array}{r}0.033 \\
(1.30)\end{array}$ \\
\hline $\begin{array}{r}0.010 \\
(5.96)\end{array}$ & $\begin{array}{r}0.010 \\
(6.16)\end{array}$ \\
\hline $\begin{array}{l}0.010 \\
(2.28)\end{array}$ & $\begin{array}{r}0.009 \\
(1.21)\end{array}$ \\
\hline $\begin{array}{l}4.454 \\
(3.09)\end{array}$ & $\begin{array}{r}2.04 \\
(0.66)\end{array}$ \\
\hline $\begin{array}{r}-0.078 \\
(-3.97)\end{array}$ & $\begin{array}{r}-0.054 \\
(-1.88)\end{array}$ \\
\hline $\begin{array}{r}-0.101 \\
(-1.89)\end{array}$ & $\begin{array}{l}-0.062 \\
(-1.10)\end{array}$ \\
\hline $\begin{array}{r}4.60 \% \\
33,385\end{array}$ & $\begin{array}{l}2.40 \% \\
10,097\end{array}$ \\
\hline
\end{tabular}


Exhibit 3

Total notional value of CDS contracts outstanding vs. number of issuers in Markit spread database Sample period: 2001 to 2006

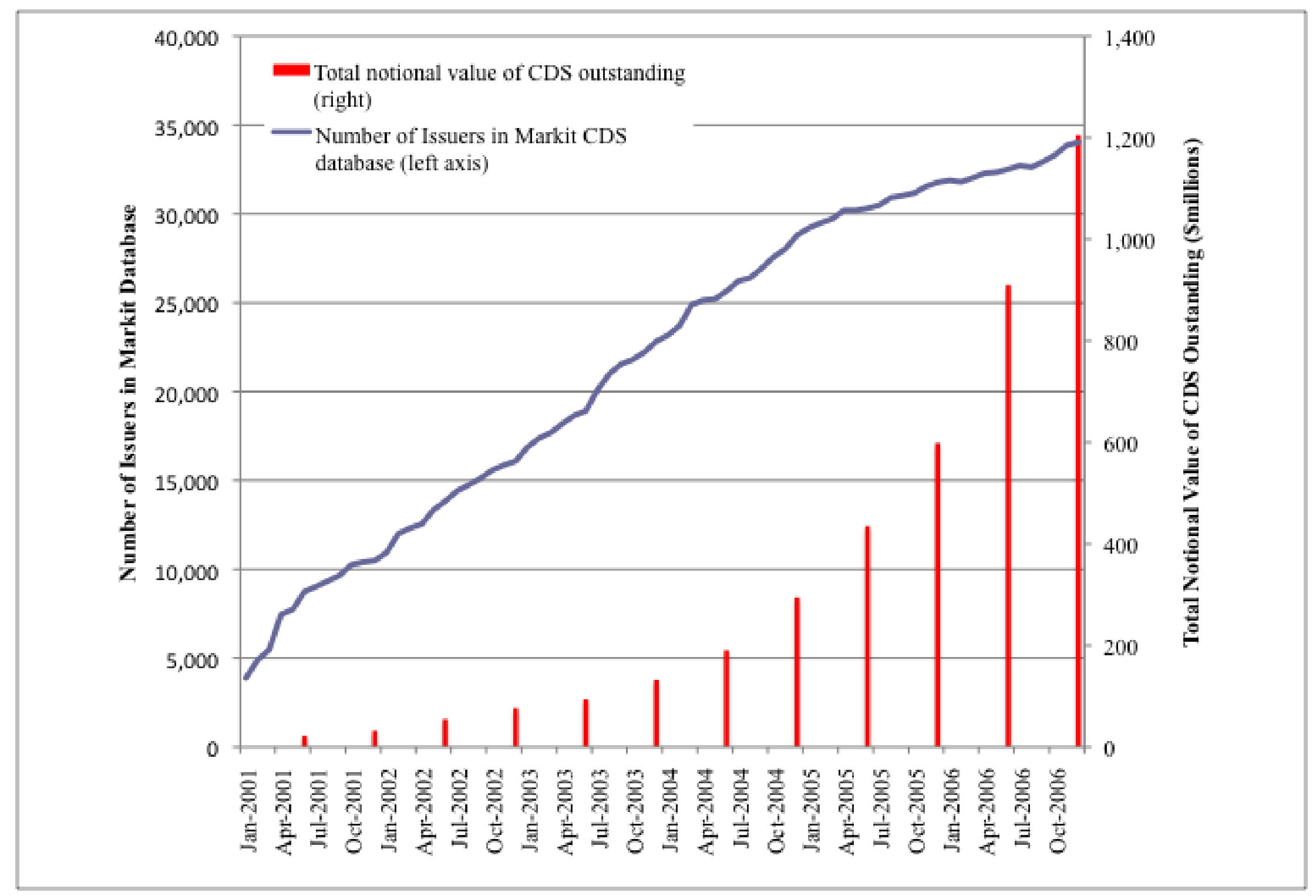


Exhibit 4

\section{Comparison of issuer and bond characteristics stratified by CDS contract activity}

Issuers were categorized every month into two groups based on whether they had had an active CDS contract to that point. Characteristics were averaged across all issuers belonging to each category every month, creating a time-series of monthly characteristics for each of the groups. $* * *, * *$, and $*$ denote significance at the $1 \%, 5 \%$, and $10 \%$ levels, respectively, for the characteristics' difference tests.

\begin{tabular}{|c|c|c|c|c|c|c|c|c|c|c|c|c|c|c|c|c|}
\hline \multirow{3}{*}{$\begin{array}{l}\text { Issuer Characteristics } \\
\text { Presence of CDS Contract: }\end{array}$} & \multicolumn{4}{|c|}{ Entire Sample Period } & \multicolumn{12}{|c|}{ Subperiods } \\
\hline & \multicolumn{4}{|c|}{ 2001-2006 } & \multicolumn{4}{|c|}{$2001-2002$} & \multicolumn{4}{|c|}{ 2003-2004 } & \multicolumn{4}{|c|}{ 2005-2006 } \\
\hline & Yes & No & Diff. & & Yes & No & Diff. & & Yes & No & Diff. & & Yes & No & Diff. & \\
\hline Average Number of Issuers & 633 & 3,963 & $-3,330$ & $* * *$ & 323 & 4,338 & $-4,015$ & $* * *$ & 654 & 3,975 & $-3,321$ & $* * *$ & 922 & 3,576 & $-2,654$ & $* * *$ \\
\hline Bond Issue Size (\$ mill) & 402 & 202 & 200 & $* * *$ & 425 & 188 & 237 & $* * *$ & 392 & 203 & 189 & $* * *$ & 388 & 216 & 172 & $* * *$ \\
\hline Time to Maturity (years) & 9 & 6 & 3 & $* * *$ & 10 & 6 & 4 & $* * *$ & 9 & 6 & 3 & $* * *$ & 8 & 6 & 2 & $* * *$ \\
\hline Credit rating & BBB & $\mathrm{BB}+$ & 2 steps & $* * *$ & $\mathrm{BBB}+$ & $\mathrm{BB}+$ & 3 steps & $* * *$ & BBB & $\mathrm{BB}+$ & 2 steps & $* * *$ & BBB- & $\mathrm{BB}+$ & 1 step & $* * *$ \\
\hline
\end{tabular}




\section{Exhibit 5}

Cross-fund bond mark dispersion before and after introduction of issuer into Markit's CDS contract spread database

Dispersion is reported for all issuers as well as subsamples split into investment grade and high yield categories. Tests compare the interquartile range of bond price marks reported by mutual funds before and after CDS contract spread information for the issuer first becomes available via the Markit database. This price dispersion measure is calculated separately for all bond mutual funds, bid-marking funds, and mid-marking funds for both a preCDS window that includes all monthly observations within the six-month period prior to the event date and a post-CDS window that includes all monthly observations within the six months period subsequent to the event date. Panel A and B present corresponding results for a full sample and a "Pre-TRACE Era" sample. The Pre-TRACE sample includes all issuers for which the CDS introduction dates occurred before the July 1, 2002 start of TRACE trade dissemination. We aggregate any multiple observations for the same issuer by averaging their corresponding dispersion measures. $\mathrm{N}$ refers to the number of issuers in each sample. Statistics for the differences in dispersion between the two data windows appear in parentheses and are based on a paired t-test.

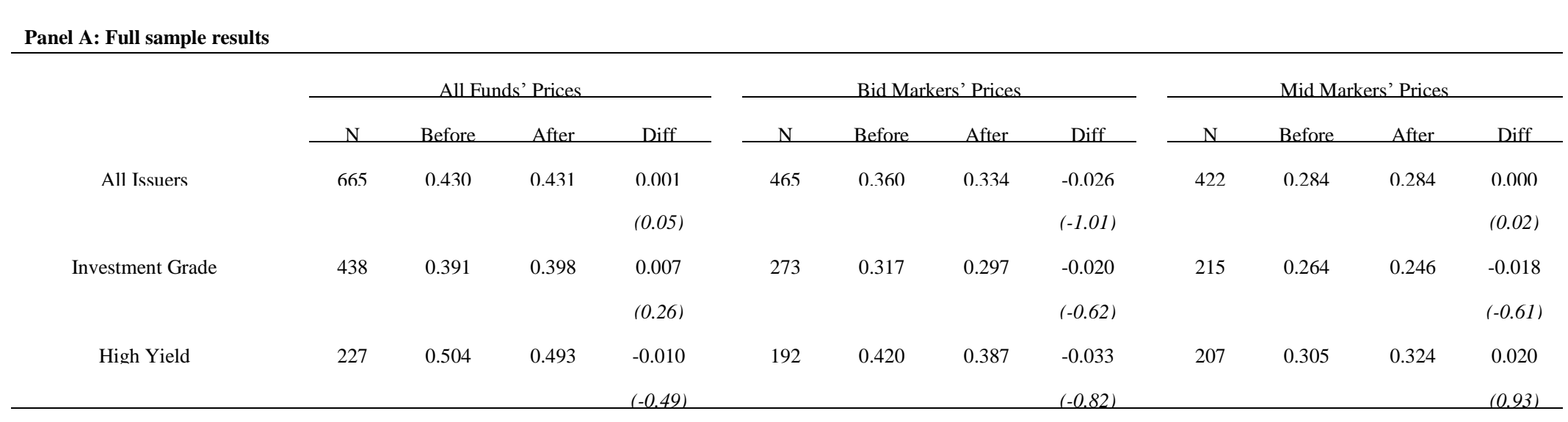

\begin{tabular}{|c|c|c|c|c|c|c|c|c|c|c|c|c|}
\hline & \multicolumn{4}{|c|}{ AllFunds' Prices } & \multicolumn{4}{|c|}{ Bid Markers' Prices } & \multicolumn{4}{|c|}{ Mid Markers' Prices } \\
\hline & $\mathrm{N}$ & Before & After & Diff & $\mathrm{N}$ & Before & After & Diff & $\mathrm{N}$ & Before & After & Diff \\
\hline \multirow[t]{2}{*}{ All Issuers } & 212 & 0.458 & 0.407 & -0.050 & 162 & 0.297 & 0.247 & -0.051 & 152 & 0.329 & 0.292 & -0.037 \\
\hline & & & & $(-1.83)$ & & & & $(-1.60)$ & & & & $(-1.41)$ \\
\hline \multirow[t]{2}{*}{ Investment Grade } & 99 & 0.395 & 0.305 & -0.090 & 65 & 0.219 & 0.143 & -0.075 & 45 & 0.316 & 0.259 & -0.057 \\
\hline & & & & $(-2.00)$ & & & & $(-2.03)$ & & & & $(-0.90)$ \\
\hline \multirow[t]{2}{*}{ High Yield } & 113 & 0.513 & 0.497 & -0.016 & 97 & 0.350 & 0.316 & -0.034 & 107 & 0.334 & 0.306 & -0.029 \\
\hline & & & & $(-0.48)$ & & & & $(-0.73)$ & & & & $(-1.09)$ \\
\hline
\end{tabular}


The authors thank Vladimir Atanasov, Daniel Foos, Bastian von Beschwitz, and, especially, Edith Hotchkiss for helpful comments and suggestions. The views expressed herein are our own and do not necessarily reflect those of the Deutsche Bundesbank.

\footnotetext{
${ }^{1}$ See Glauber's remarks at the Securities Industry Association's Market Structure Conference on June 7, 2002: http://www.finra.org/Newsroom/Speeches/Glauber/P011002.

${ }^{2}$ Such concern is well founded in light of the Edwards, Harris, and Piwowar (2007) finding that about $40 \%$ of all corporate bond trades are for amounts smaller than $\$ 100,000$.

${ }^{3}$ See again "Bonds' pricing is questioned in email trail," The Wall Street Journal, October 26, 2007, C1 (Susan Pulliam).

${ }^{4}$ See "An analysis and description of pricing and information sources in the securitized and structured finance markets," The Bond Market Association and The American Securitization Forum, October 2006.

${ }^{5}$ We ignore all bond positions smaller than $\$ 10,000$ in par value and round our calculated bond prices to the fourth decimal point to avoid spurious differences due to rounding errors.

${ }^{6}$ Mid- and bid-marking funds are those that state their respective use of mid and bid quotes in their prospectuses.

7 Until February 7, 2005, the dissemination of some trades in these bonds was subject to a time delay. Bonds rated A or better that were under $\$ 100$ million in size were also disseminated on October 1, 2004. However, this group is not well represented in our fund holdings sample.

${ }^{8}$ T-statistics, presented in parentheses, are based on Rogers [1993] standard errors clustered by bond and period. An expanded model where bonds with a sibling among the 120 disseminated bonds could experience a dispersion decline after April 13, 2003 larger than for other bonds without such a sibling yielded inconclusive results.

${ }^{9}$ The statistical insignificance may be due to lack of power owing to relatively small sample sizes for the interaction subgoups. To be included in an interaction subgroup, a bond must be held by three mutual funds and appear in Markit's CDS spread database in the periods before and after the TRACE dissemination date. Relatively few bonds meet these criteria.
} 
CfR working paper series

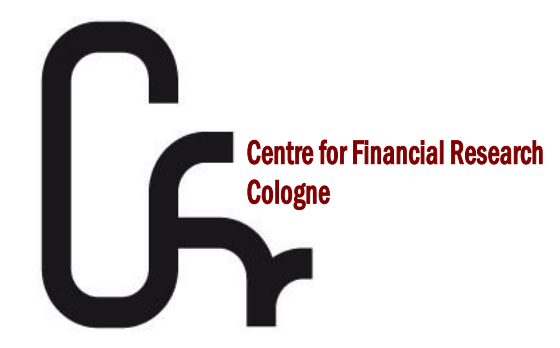

CFR Working Papers are available for download from www.cfr-cologne.de.

Hardcopies can be ordered from: Centre for Financial Research (CFR), Albertus Magnus Platz, 50923 Koeln, Germany.

\section{4}

No. Author(s) Title

14-04 C. Sorhage

14-03 D. Hess, P. Immenkötter

14-02 C. Andres, M. Doumet, E. The Lintner model revisited: Dividends versus total payouts Fernau, E. Theissen

14-01 N.F. Carline, S. C. Linn, P. Corporate Governance and the Nature of Takeover Resistance K. Yadav
Outsourcing of Mutual Funds' Non-core Competencies and the Impact on Operational Outcomes: Evidence from Funds' Shareholder Services

How Much Is Too Much? Debt Capacity And Financial Flexibility

\section{3}

No. Author(s) Title

13-11 R. Baule, O. Korn, S. Saßning

Which Beta is Best?

On the Information Content of Option-implied Betas

$13-10$

V. Agarwal, L. Ma

Managerial Multitasking in the Mutual Fund Industry

13-09 M. J. Kamstra, L.A. Kramer, M.D. Levi, R.

Seasonal Asset Allocation: Evidence from Wermers Mutual Fund Flows

13-08 F. Brinkmann, A. Kempf, O. Korn

Forward-Looking Measures of Higher-Order Dependencies with an Application to Portfolio Selection

13-07 G. Cici, S. Gibson, Y. Gunduz, J.J. Merrick, Jr.

Market Transparency and the Marking Precision of Bond Mutual Fund Managers

13-06 S.Bethke, A. Kempf, M. Trapp

The Correlation Puzzle: The Interaction of Bond and Risk Correlation

13-05 P. Schuster, M. Trapp, M. Uhrig-Homburg

A Heterogeneous Agents Equilibrium Model for the Term Structure of Bond Market Liquidity

13-04 V. Agarwal, K. Mullally, Y. Tang, B. Yang

Mandatory Portfolio Disclosure, Stock Liquidity, and Mutual Fund Performance 
13-03 V. Agarwal, V. Nanda, S.Ray

$13-02$

C. Andres, A. Betzer,

M. Doumet, E. Theissen

13-01 J. Gaul, E. Theissen
Institutional Investment and Intermediation in the Hedge Fund Industry

Open Market Share Repurchases in Germany: A Conditional Event Study Approach

A Partially Linear Approach to Modelling the Dynamics of Spot and Futures Price

2012

\begin{tabular}{|c|c|c|}
\hline No. & Author(s) & Title \\
\hline $12-12$ & $\begin{array}{l}\text { Y. Gündüz, J. Nasev, } \\
\text { M. Trapp }\end{array}$ & The Price Impact of CDS Trading \\
\hline $12-11$ & $\begin{array}{l}\text { Y. Wu, R. Wermers, } \\
\text { J. Zechner }\end{array}$ & $\begin{array}{l}\text { Governance and Shareholder Value in Delegated Portfolio } \\
\text { Management: The Case of Closed-End Funds }\end{array}$ \\
\hline $12-10$ & M. Trapp, C. Wewel & Transatlantic Systemic Risk \\
\hline $12-09$ & $\begin{array}{l}\text { G. Cici, A. Kempf, } \\
\text { C. Sorhage }\end{array}$ & $\begin{array}{l}\text { Do Financial Advisors Provide Tangible Benefits for Investors? } \\
\text { Evidence from Tax-Motivated Mutual Fund Flows }\end{array}$ \\
\hline $12-08$ & S. Jank & $\begin{array}{l}\text { Changes in the composition of publicly traded firms: } \\
\text { Implications for the dividend-price ratio and return predictability }\end{array}$ \\
\hline $12-07$ & G. Cici, C. Rosenfeld & The Investment Abilities of Mutual Fund Buy-Side Analysts \\
\hline $12-06$ & $\begin{array}{l}\text { A. Kempf, A. Pütz, } \\
\text { F. Sonnenburg }\end{array}$ & $\begin{array}{l}\text { Fund Manager Duality: Impact on Performance and Investment } \\
\text { Behavior }\end{array}$ \\
\hline $12-05$ & R. Wermers & Runs on Money Market Mutual Funds \\
\hline $12-04$ & R. Wermers & $\begin{array}{l}\text { A matter of style: The causes and consequences of style drift } \\
\text { in institutional portfolios }\end{array}$ \\
\hline $12-02$ & $\begin{array}{l}\text { C. Andres, E. Fernau, } \\
\text { E. Theissen }\end{array}$ & $\begin{array}{l}\text { Should I Stay or Should I Go? } \\
\text { Former CEOs as Monitors }\end{array}$ \\
\hline $12-01$ & L. Andreu, A. Pütz & $\begin{array}{l}\text { Are Two Business Degrees Better Than One? } \\
\text { Evidence from Mutual Fund Managers' Education }\end{array}$ \\
\hline
\end{tabular}

\section{1}

No.

Author(s)

Title

11-16 V. Agarwal, J.-P. Gómez,

R. Priestley

Management Compensation and Market Timing under Portfolio Constraints

11-15 T. Dimpfl, S. Jank

Can Internet Search Queries Help to Predict Stock Market Volatility?

11-14 P. Gomber,

U. Schweickert,

Liquidity Dynamics in an Electronic Open Limit Order Book:

E. Theissen

An Event Study Approach

11-13 D. Hess, S. Orbe

Irrationality or Efficiency of Macroeconomic Survey Forecasts? Implications from the Anchoring Bias Test 


\begin{tabular}{|c|c|c|}
\hline $11-11$ & $\begin{array}{l}\text { N. Heinrichs, D. Hess, } \\
\text { C. Homburg, M. Lorenz, } \\
\text { S. Sievers }\end{array}$ & $\begin{array}{l}\text { Extended Dividend, Cash Flow and Residual Income Valuation } \\
\text { Models - Accounting for Deviations from Ideal Conditions }\end{array}$ \\
\hline $11-10$ & $\begin{array}{l}\text { A. Kempf, O. Korn, } \\
\text { S. Saßning }\end{array}$ & Portfolio Optimization using Forward - Looking Information \\
\hline $11-09$ & V. Agarwal, S. Ray & $\begin{array}{l}\text { Determinants and Implications of Fee Changes in the Hedge } \\
\text { Fund Industry }\end{array}$ \\
\hline 11-08 & G. Cici, L.-F. Palacios & $\begin{array}{l}\text { On the Use of Options by Mutual Funds: Do They Know What } \\
\text { They Are Doing? }\end{array}$ \\
\hline 11-07 & $\begin{array}{l}\text { V. Agarwal, G. D. Gay, } \\
\text { L. Ling }\end{array}$ & $\begin{array}{l}\text { Performance inconsistency in mutual funds: An investigation of } \\
\text { window-dressing behavior }\end{array}$ \\
\hline 11-06 & $\begin{array}{l}\text { N. Hautsch, D. Hess, } \\
\text { D. Veredas }\end{array}$ & $\begin{array}{l}\text { The Impact of Macroeconomic News on Quote Adjustments, } \\
\text { Noise, and Informational Volatility }\end{array}$ \\
\hline $11-05$ & G. Cici & $\begin{array}{l}\text { The Prevalence of the Disposition Effect in Mutual Funds' } \\
\text { Trades }\end{array}$ \\
\hline 11-04 & S. Jank & Mutual Fund Flows, Expected Returns and the Real Economy \\
\hline 11-03 & G.Fellner, E.Theissen & $\begin{array}{l}\text { Short Sale Constraints, Divergence of Opinion and Asset } \\
\text { Value: Evidence from the Laboratory }\end{array}$ \\
\hline 11-02 & S.Jank & Are There Disadvantaged Clienteles in Mutual Funds? \\
\hline 11-01 & V. Agarwal, C. Meneghetti & The Role of Hedge Funds as Primary Lenders \\
\hline
\end{tabular}

2010

No. Author(s) Title

10-20 G. Cici, S. Gibson, Missing the Marks? Dispersion in Corporate Bond Valuations J.J. Merrick Jr. Across Mutual Funds

10-19 J. Hengelbrock, Market Response to Investor Sentiment

E. Theissen, C. Westheide

10-18 G. Cici, S. Gibson The Performance of Corporate-Bond Mutual Funds:

Evidence Based on Security-Level Holdings

10-17 D. Hess, D. Kreutzmann, Projected Earnings Accuracy and the Profitability of Stock

O. Pucker Recommendations

10-16 S. Jank, M. Wedow Sturm und Drang in Money Market Funds: When Money

Market Funds Cease to Be Narrow

10-15 G. Cici, A. Kempf, A. The Valuation of Hedge Funds' Equity Positions Puetz

10-14 J. Grammig, S. Jank

Creative Destruction and Asset Prices

10-13 S. Jank, M. Wedow

Purchase and Redemption Decisions of Mutual Fund Investors and the Role of Fund Families

10-12 S. Artmann, P. Finter,

The Cross-Section of German Stock Returns:

A. Kempf, S. Koch,

E. Theissen

10-11 M. Chesney, A. Kempf

New Data and New Evidence

10-10 S. Frey, P. Herbst

The Value of Tradeability

The Influence of Buy-side Analysts on

Mutual Fund Trading

10-09 V. Agarwal, W. Jiang, Y. Tang, B. Yang

Uncovering Hedge Fund Skill from the Portfolio Holdings They Hide 
10-08 V. Agarwal, V. Fos, W. Jiang

10-07 V. Agarwal, G. Bakshi, J. Huij

10-06 J. Grammig, F. J. Peter

10-05 K. Drachter, A. Kempf

10-04 J. Fang, A. Kempf, M. Trapp

10-03 P. Finter, A. NiessenRuenzi, S. Ruenzi

10-02 D. Hunter, E. Kandel, S. Kandel, R. Wermers

10-01 S. Artmann, P. Finter, A. Kempf
Inferring Reporting Biases in Hedge Fund Databases from Hedge Fund Equity Holdings

Do Higher-Moment Equity Risks Explain Hedge Fund Returns?

Tell-Tale Tails

Höhe, Struktur und Determinanten der ManagervergütungEine Analyse der Fondsbranche in Deutschland

Fund Manager Allocation

The Impact of Investor Sentiment on the German Stock Market

Mutual Fund Performance Evaluation with Active Peer Benchmarks

Determinants of Expected Stock Returns: Large Sample Evidence from the German Market

2009

No. Author(s)

09-17

E. Theissen

$09-16$

M. Trapp

$09-15$

A. Betzer, J. Gider, D.Metzger, E. Theissen

09-14 A. Kempf, O. Korn, M. Uhrig-Homburg

09-13 W. Bühler, M. Trapp

09-12 W. Bühler, M. Trapp

09-11 S. J. Taylor, P. K. Yadav, Y. Zhang

09-10 A. Kempf, C. Merkle, A. Niessen-Ruenzi

09-09 V. Fotak, V. Raman, P. K. Yadav

09-08 F. Bardong, S.M. Bartram P.K. Yadav

09-07 S. J. Taylor, P. K. Yadav, Y. Zhang

09-06

S. Frey, P. Sandas

09-05

H. Beltran-Lopez, P. Giot, J. Grammig
Title

Price Discovery in Spot and Futures Markets:

A Reconsideration

Trading the Bond-CDS Basis - The Role of Credit Risk and Liquidity

Strategic Trading and Trade Reporting by Corporate Insiders

The Term Structure of Illiquidity Premia

Time-Varying Credit Risk and Liquidity Premia in Bond and CDS Markets

Explaining the Bond-CDS Basis - The Role of Credit Risk and Liquidity

Cross-sectional analysis of risk-neutral skewness

Low Risk and High Return - Affective Attitudes and Stock Market Expectations

Naked Short Selling: The Emperor`s New Clothes?

Informed Trading, Information Asymmetry and Pricing of Information Risk: Empirical Evidence from the NYSE

The information content of implied volatilities and model-free volatility expectations: Evidence from options written on individual stocks

The Impact of Iceberg Orders in Limit Order Books

Commonalities in the Order Book

Rapid Trading bei deutschen Aktienfonds:

Evidenz aus einer großen deutschen Fondsgesellschaft 
09-03 A. Banegas, B. Gillen,

A. Timmermann,

R. Wermers

$09-02$

J. Grammig, A. Schrimpf,

M. Schuppli

09-01 O. Korn, P. Koziol
The Cross-Section of Conditional Mutual Fund Performance in European Stock Markets

Long-Horizon Consumption Risk and the Cross-Section of Returns: New Tests and International Evidence

The Term Structure of Currency Hedge Ratios

2008

\begin{tabular}{|c|c|c|}
\hline No. & Author(s) & Title \\
\hline $08-12$ & $\begin{array}{l}\text { U. Bonenkamp, } \\
\text { C. Homburg, A. Kempf }\end{array}$ & Fundamental Information in Technical Trading Strategies \\
\hline $08-11$ & O. Korn & Risk Management with Default-risky Forwards \\
\hline $08-10$ & J. Grammig, F.J. Peter & $\begin{array}{l}\text { International Price Discovery in the Presence } \\
\text { of Market Microstructure Effects }\end{array}$ \\
\hline 08-09 & C. M. Kuhnen, A. Niessen & Public Opinion and Executive Compensation \\
\hline $08-08$ & A. Pütz, S. Ruenzi & $\begin{array}{l}\text { Overconfidence among Professional Investors: Evidence from } \\
\text { Mutual Fund Managers }\end{array}$ \\
\hline 08-07 & P. Osthoff & What matters to SRI investors? \\
\hline 08-06 & A. Betzer, E. Theissen & $\begin{array}{l}\text { Sooner Or Later: Delays in Trade Reporting by Corporate } \\
\text { Insiders }\end{array}$ \\
\hline 08-05 & P. Linge, E. Theissen & $\begin{array}{l}\text { Determinanten der Aktionärspräsenz auf } \\
\text { Hauptversammlungen deutscher Aktiengesellschaften }\end{array}$ \\
\hline $08-04$ & $\begin{array}{l}\text { N. Hautsch, D. Hess, } \\
\text { C. Müller }\end{array}$ & Price Adjustment to News with Uncertain Precision \\
\hline $08-03$ & $\begin{array}{l}\text { D. Hess, H. Huang, } \\
\text { A. Niessen }\end{array}$ & $\begin{array}{l}\text { How Do Commodity Futures Respond to Macroeconomic } \\
\text { News? }\end{array}$ \\
\hline 08-02 & $\begin{array}{l}\text { R. Chakrabarti, } \\
\text { W. Megginson, P. Yadav }\end{array}$ & Corporate Governance in India \\
\hline 08-01 & C. Andres, E. Theissen & $\begin{array}{l}\text { Setting a Fox to Keep the Geese - Does the Comply-or-Explain } \\
\text { Principle Work? }\end{array}$ \\
\hline
\end{tabular}

\section{7}

No.

Author(s)

Title

07-16 M. Bär, A. Niessen,

S. Ruenzi

07-15 A. Niessen, S. Ruenzi

07-14 O. Korn

07-13 A. Kempf, P. Osthoff

07-12 J. Grammig, E. Theissen, Time and Price Impact of a Trade: A Structural Approach O. Wuensche

07-11 V. Agarwal, J. R. Kale

07-10 M. Kasch-Haroutounian,

E. Theissen
The Impact of Work Group Diversity on Performance: Large Sample Evidence from the Mutual Fund Industry

Political Connectedness and Firm Performance: Evidence From Germany

Hedging Price Risk when Payment Dates are Uncertain

SRI Funds: Nomen est Omen

On the Relative Performance of Multi-Strategy and Funds of Hedge Funds

Competition Between Exchanges: Euronext versus Xetra 


\begin{tabular}{|c|c|c|}
\hline 07-09 & $\begin{array}{l}\text { V. Agarwal, N. D. Daniel, } \\
\text { N. Y. Naik }\end{array}$ & Do hedge funds manage their reported returns? \\
\hline 07-08 & $\begin{array}{l}\text { N. C. Brown, K. D. Wei, } \\
\text { R. Wermers }\end{array}$ & $\begin{array}{l}\text { Analyst Recommendations, Mutual Fund Herding, and } \\
\text { Overreaction in Stock Prices }\end{array}$ \\
\hline 07-07 & A. Betzer, E. Theissen & $\begin{array}{l}\text { Insider Trading and Corporate Governance: } \\
\text { The Case of Germany }\end{array}$ \\
\hline 07-06 & V. Agarwal, L. Wang & Transaction Costs and Value Premium \\
\hline 07-05 & J. Grammig, A. Schrimpf & $\begin{array}{l}\text { Asset Pricing with a Reference Level of Consumption: } \\
\text { New Evidence from the Cross-Section of Stock Returns }\end{array}$ \\
\hline 07-04 & $\begin{array}{l}\text { V. Agarwal, N.M. Boyson, } \\
\text { N.Y. Naik }\end{array}$ & $\begin{array}{l}\text { Hedge Funds for retail investors? } \\
\text { An examination of hedged mutual funds }\end{array}$ \\
\hline 07-03 & D. Hess, A. Niessen & $\begin{array}{l}\text { The Early News Catches the Attention: } \\
\text { On the Relative Price Impact of Similar Economic Indicators }\end{array}$ \\
\hline 07-02 & $\begin{array}{l}\text { A. Kempf, S. Ruenzi, } \\
\text { T. Thiele }\end{array}$ & $\begin{array}{l}\text { Employment Risk, Compensation Incentives and Managerial } \\
\text { Risk Taking - Evidence from the Mutual Fund Industry - }\end{array}$ \\
\hline 07-01 & M. Hagemeister, A. Kempf & $\begin{array}{l}\text { CAPM und erwartete Renditen: Eine Untersuchung auf Basis } \\
\text { der Erwartung von Marktteilnehmern }\end{array}$ \\
\hline
\end{tabular}

2006

\begin{tabular}{|c|c|c|}
\hline No. & Author(s) & Title \\
\hline 06-13 & $\begin{array}{l}\text { S. Čeljo-Hörhager, } \\
\text { A. Niessen }\end{array}$ & $\begin{array}{l}\text { How do Self-fulfilling Prophecies affect Financial Ratings? - An } \\
\text { experimental study }\end{array}$ \\
\hline 06-12 & $\begin{array}{l}\text { R. Wermers, Y. Wu, } \\
\text { J. Zechner }\end{array}$ & $\begin{array}{l}\text { Portfolio Performance, Discount Dynamics, and the Turnover } \\
\text { of Closed-End Fund Managers }\end{array}$ \\
\hline 06-11 & $\begin{array}{l}\text { U. v. Lilienfeld-Toal, } \\
\text { S. Ruenzi }\end{array}$ & $\begin{array}{l}\text { Why Managers Hold Shares of Their Firm: An Empirical } \\
\text { Analysis }\end{array}$ \\
\hline 06-10 & A. Kempf, P. Osthoff & $\begin{array}{l}\text { The Effect of Socially Responsible Investing on Portfolio } \\
\text { Performance }\end{array}$ \\
\hline 06-09 & $\begin{array}{l}\text { R. Wermers, T. Yao, } \\
\text { J. Zhao }\end{array}$ & $\begin{array}{l}\text { Extracting Stock Selection Information from Mutual Fund } \\
\text { holdings: An Efficient Aggregation Approach }\end{array}$ \\
\hline 06-08 & M. Hoffmann, B. Kempa & $\begin{array}{l}\text { The Poole Analysis in the New Open Economy } \\
\text { Macroeconomic Framework }\end{array}$ \\
\hline 06-07 & $\begin{array}{l}\text { K. Drachter, A. Kempf, } \\
\text { M. Wagner }\end{array}$ & $\begin{array}{l}\text { Decision Processes in German Mutual Fund Companies: } \\
\text { Evidence from a Telephone Survey }\end{array}$ \\
\hline 06-06 & $\begin{array}{l}\text { J.P. Krahnen, F.A. } \\
\text { Schmid, E. Theissen }\end{array}$ & $\begin{array}{l}\text { Investment Performance and Market Share: A Study of the } \\
\text { German Mutual Fund Industry }\end{array}$ \\
\hline 06-05 & S. Ber, S. Ruenzi & $\begin{array}{l}\text { On the Usability of Synthetic Measures of Mutual Fund Net- } \\
\text { Flows }\end{array}$ \\
\hline 06-04 & A. Kempf, D. Mayston & Liquidity Commonality Beyond Best Prices \\
\hline 06-03 & O. Korn, C. Koziol & Bond Portfolio Optimization: A Risk-Return Approach \\
\hline 06-02 & $\begin{array}{l}\text { O. Scaillet, L. Barras, R. } \\
\text { Wermers }\end{array}$ & $\begin{array}{l}\text { False Discoveries in Mutual Fund Performance: Measuring } \\
\text { Luck in Estimated Alphas }\end{array}$ \\
\hline 06-01 & A. Niessen, S. Ruenzi & Sex Matters: Gender Differences in a Professional Setting \\
\hline
\end{tabular}




\begin{tabular}{|c|c|c|}
\hline No. & Author(s) & Title \\
\hline $05-16$ & E. Theissen & $\begin{array}{l}\text { An Analysis of Private Investors' Stock Market Return } \\
\text { Forecasts }\end{array}$ \\
\hline $05-15$ & $\begin{array}{l}\text { T. Foucault, S. Moinas, } \\
\text { E. Theissen }\end{array}$ & Does Anonymity Matter in Electronic Limit Order Markets \\
\hline $05-14$ & $\begin{array}{l}\text { R. Kosowski, } \\
\text { A. Timmermann, } \\
\text { R. Wermers, H. White }\end{array}$ & $\begin{array}{l}\text { Can Mutual Fund „Stars“ Really Pick Stocks? } \\
\text { New Evidence from a Bootstrap Analysis }\end{array}$ \\
\hline $05-13$ & D. Avramov, R. Wermers & Investing in Mutual Funds when Returns are Predictable \\
\hline $05-12$ & K. Griese, A. Kempf & Liquiditätsdynamik am deutschen Aktienmarkt \\
\hline $05-11$ & $\begin{array}{l}\text { S. Ber, A. Kempf, } \\
\text { S. Ruenzi }\end{array}$ & Determinanten der Mittelzuflüsse bei deutschen Aktienfonds \\
\hline $05-10$ & $\begin{array}{l}\text { M. Bär, A. Kempf, } \\
\text { S. Ruenzi }\end{array}$ & $\begin{array}{l}\text { Is a Team Different From the Sum of Its Parts? } \\
\text { Evidence from Mutual Fund Managers }\end{array}$ \\
\hline 05-09 & M. Hoffmann & Saving, Investment and the Net Foreign Asset Position \\
\hline 05-08 & S. Ruenzi & $\begin{array}{l}\text { Mutual Fund Growth in Standard and Specialist Market } \\
\text { Segments }\end{array}$ \\
\hline 05-07 & A. Kempf, S. Ruenzi & $\begin{array}{l}\text { Status Quo Bias and the Number of Alternatives - An Empirical } \\
\text { Illustration from the Mutual Fund Industry }\end{array}$ \\
\hline 05-06 & J. Grammig, E. Theissen & $\begin{array}{l}\text { Is Best Really Better? Internalization of Orders in an Open } \\
\text { Limit Order Book }\end{array}$ \\
\hline 05-05 & $\begin{array}{l}\text { H. Beltran-Lopez, J. } \\
\text { Grammig, A.J. Menkveld }\end{array}$ & Limit order books and trade informativeness \\
\hline 05-04 & M. Hoffmann & Compensating Wages under different Exchange rate Regimes \\
\hline $05-03$ & M. Hoffmann & $\begin{array}{l}\text { Fixed versus Flexible Exchange Rates: Evidence from } \\
\text { Developing Countries }\end{array}$ \\
\hline 05-02 & A. Kempf, C. Memmel & Estimating the Global Minimum Variance Portfolio \\
\hline $05-01$ & S. Frey, J. Grammig & $\begin{array}{l}\text { Liquidity supply and adverse selection in a pure limit order } \\
\text { book market }\end{array}$ \\
\hline
\end{tabular}

\section{4}

No. Author(s) Title

04-10 N. Hautsch, D. Hess

Bayesian Learning in Financial Markets - Testing for the Relevance of Information Precision in Price Discovery

04-09 A. Kempf, K. Kreuzberg

Portfolio Disclosure, Portfolio Selection and Mutual Fund Performance Evaluation

04-08 N.F. Carline, S.C. Linn, P.K. Yadav Operating performance changes associated with corporate mergers and the role of corporate governance

04-07 J.J. Merrick, Jr., N.Y. Naik, Strategic Trading Behaviour and Price Distortion in a P.K. Yadav Manipulated Market: Anatomy of a Squeeze

04-06 N.Y. Naik, P.K. Yadav

Trading Costs of Public Investors with Obligatory and Voluntary Market-Making: Evidence from Market Reforms

04-05 A. Kempf, S. Ruenzi

Family Matters: Rankings Within Fund Families and Fund Inflows 
04-04 V. Agarwal, N.D. Daniel, N.Y. Naik

04-03 V. Agarwal, W.H. Fung, J.C. Loon, N.Y. Naik

04-02 A. Kempf, S. Ruenzi

04-01 I. Chowdhury, M. Hoffmann, A. Schabert
Role of Managerial Incentives and Discretion in Hedge Fund Performance

Risk and Return in Convertible Arbitrage:

Evidence from the Convertible Bond Market

Tournaments in Mutual Fund Families

Inflation Dynamics and the Cost Channel of Monetary

Transmission 